"This document is the Accepted Manuscript version of a Published Work that appeared in final form in Inorg. Chem. 2014, 53, 11675-11681, copyright (C) American Chemical Society after peer review and technical editing by the publisher. To access the final edited and published work see DOI: 10.1021/ic501883z. This article may be used for non-commercial purposes in accordance with the ACS guidelines published at http://pubs.acs.org/page/policy/articlesonrequest/index.html]." 


\section{Synthesis and Structural Features of Co(II) and}

\section{Co(III) Complexes Supported by Amino- trisphenolate Ligand Scaffolds}

Carmen Martín, ${ }^{\dagger}$ Christopher J. Whiteoak,$^{\dagger}$ Eddy Martin, ${ }^{\dagger}$ Eduardo C. Escudero-Adán,,$^{\dagger}$ José Ramón Galán-Mascarós, ${ }^{\dagger}$, Arjan W. Kleij ${ }^{*}, \dot{\$}$,

†Institute of Chemical Research of Catalonia (ICIQ), Av. Països Catalans 16, 43007 Tarragona, Spain.

$\S$ Catalan Institute of Research and Advanced Studies (ICREA), Pg. Lluís Companys 23, 08010 Barcelona, Spain. 
ABSTRACT: $\mathrm{Co}(\mathrm{II})$ complexes of amino-trisphenolate $\left((\mathrm{ArO})_{3} \mathrm{~N}^{3-}\right)$ ligands can be prepared straightforwardly in high yield. X-ray analysis reveals these complexes to comprise of two different hemi-spheres, one containing an anionic $\operatorname{Co}\left((\mathrm{ArO})_{3} \mathrm{~N}\right)^{-}$and the other a cationic $(\mathrm{ArO})_{3} \mathrm{NH}^{+}$unit which are associated through hydrogen bonding. These $\mathrm{Co}(\mathrm{II})$ complexes can be easily converted into their $\mathrm{Co}$ (III) analogues in air in the presence of suitable bases such as dimethylaminopyridine (DMAP) and 2,2'-bipyridine (bipy), and the structural features and magnetic properties of these latter compounds are also reported. 


\section{- INTRODUCTION}

The use of amino-trisphenolate ligands (abbreviated as $(\mathrm{ArOH})_{3} \mathrm{~N}$ ligands) in inorganic and catalysis related research is an active area of science with an ever increasing impact in several communities. ${ }^{1}$ These $(\mathrm{ArO})_{3} \mathrm{~N}$-chelating ligands combine a potentially multi-dentate coordination ability with relative ease for variation of the ligand through synthetic modulation. As such, complexes of these ligands have recently been the basis of several new catalyst systems for a variety of applications involving high-valent metals including $\mathrm{Ti}(\mathrm{IV}),{ }^{2 \mathrm{a}-\mathrm{b}} \mathrm{V}(\mathrm{V}),{ }^{2 \mathrm{c}} \mathrm{Mo}(\mathrm{VI}),{ }^{2 \mathrm{~d}}$ $\mathrm{Zr} / \mathrm{Hf}(\mathrm{IV}),{ }^{2 \mathrm{e}} \mathrm{U}(\mathrm{IV}),{ }^{2 \mathrm{f}} \mathrm{Fe}(\mathrm{III}),{ }^{2 \mathrm{~g}-\mathrm{i}}$ and $\mathrm{Al}(\mathrm{III}){ }^{2 \mathrm{j}-1}$ Recently, the first examples of $\mathrm{Co}(\mathrm{II})(\mathrm{ArO}){ }_{3} \mathrm{~N}$ complexes which contain bulky ortho-groups attached to the ligand framework have been reported, ${ }^{3}$ as a prelude to activation of small molecules such as dioxygen. In addition to the use of these $(\mathrm{ArO})_{3} \mathrm{~N}$-chelating ligands, there are many examples of other tripodal (hybrid) ligands systems that have been shown to incorporate $\mathrm{Co}$ (II) ions, ${ }^{4}$ having in most cases a $\mathrm{N}_{4}$-chelating character such as in amino-trispyridyl (TPA) ligands. However, (reactivity) studies involving the formation of $\mathrm{Co}(\mathrm{III})$ complexes of these aforementioned ligands are limited $\mathrm{d}^{4 \mathrm{f}, \mathrm{h}-\mathrm{i}}$ and to the best of our knowledge $\mathrm{Co}(\mathrm{III})(\mathrm{ArO})_{3} \mathrm{~N}$ species have thus far not been crystallographically characterized.

The chemistry of Co(III)-salen complexes has been well-developed over the years and shown to be of eminent use in catalytic operations focusing on kinetic resolution of $(\mathrm{rac})$-epoxides ${ }^{5}$ and their copolymerization with carbon dioxide $\left(\mathrm{CO}_{2}\right)$ forming useful polycarbonates, ${ }^{6}$ with further reports also detailing other types of catalysis with these complexes. ${ }^{7}$ Mechanistic studies have revealed that in these copolymerization reactions a bimetallic transition state ${ }^{8}$ is operative activating two substrate molecules leading to a more efficient conversion and improved reactivity and/or selectivity behavior. We recently found that $(\mathrm{ArO})_{3} \mathrm{~N}$ based complexes of $\mathrm{Fe}(\mathrm{III})^{2 \mathrm{~g}}$ and $\mathrm{Al}(\mathrm{III})^{2 \mathrm{k}}$ have the ability to form hexa-coordinated structures with two cis-positioned coordination sites for 
incoming substrates. This effect of an external ligand or substrate on the overall conformation and fluxionality of amino-trisphenolate complexes has been reported before for Ti(IV) based systems; ${ }^{9}$ Zonta et al. reported in this respect an interesting $\mathrm{Ti}(\mathrm{IV})$ peroxo complex ${ }^{9 \mathrm{~b}}$ that after coordination of a solvent molecule changes its coordination geometry and enables oxygen-transfer catalysis. Further to this, the Fe(III) family of complexes was also shown to efficiently catalyze the formation of poly(cyclohexene)carbonate similar to the aforementioned $\mathrm{Co}(\mathrm{III})$-salen complexes. ${ }^{10}$ As a result we hypothesized that two available cis-coordination sites on a Co(III) center could be highly useful for the formation of organic carbonates from epoxides and $\mathrm{CO}_{2}$ and therefore started to combine our interest in $(\mathrm{ArO})_{3} \mathrm{~N}$ ligands and the highly successful application of $\mathrm{Co}(\mathrm{III})$ chemistry to mediate these epoxide $/ \mathrm{CO}_{2}$ couplings. Herein we report the first synthesis and full structural characterization of $\mathrm{Co}(\mathrm{III})(\mathrm{ArO})_{3} \mathrm{~N}$ complexes. 


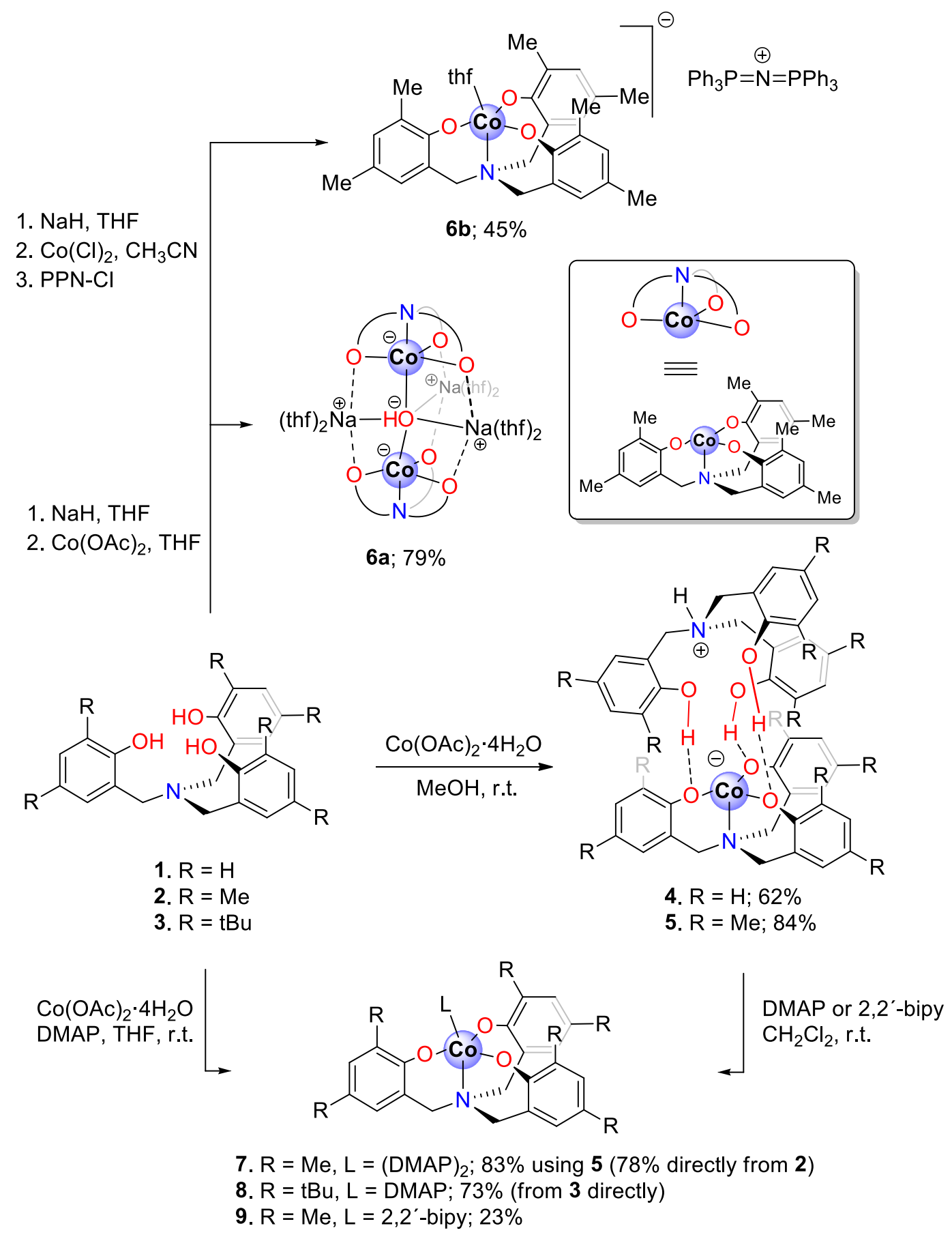

Scheme 1. Synthesis of Co(II) and Co(III) complexes 4-9 from amino-triphenol ligand precursors 1-3. Note that the protonated $(\mathrm{ArO})_{3} \mathrm{NH}^{+}$ligand in complexes $\mathbf{4}$ and $\mathbf{5}$ forms an ion pair with the Co(II) complex. 


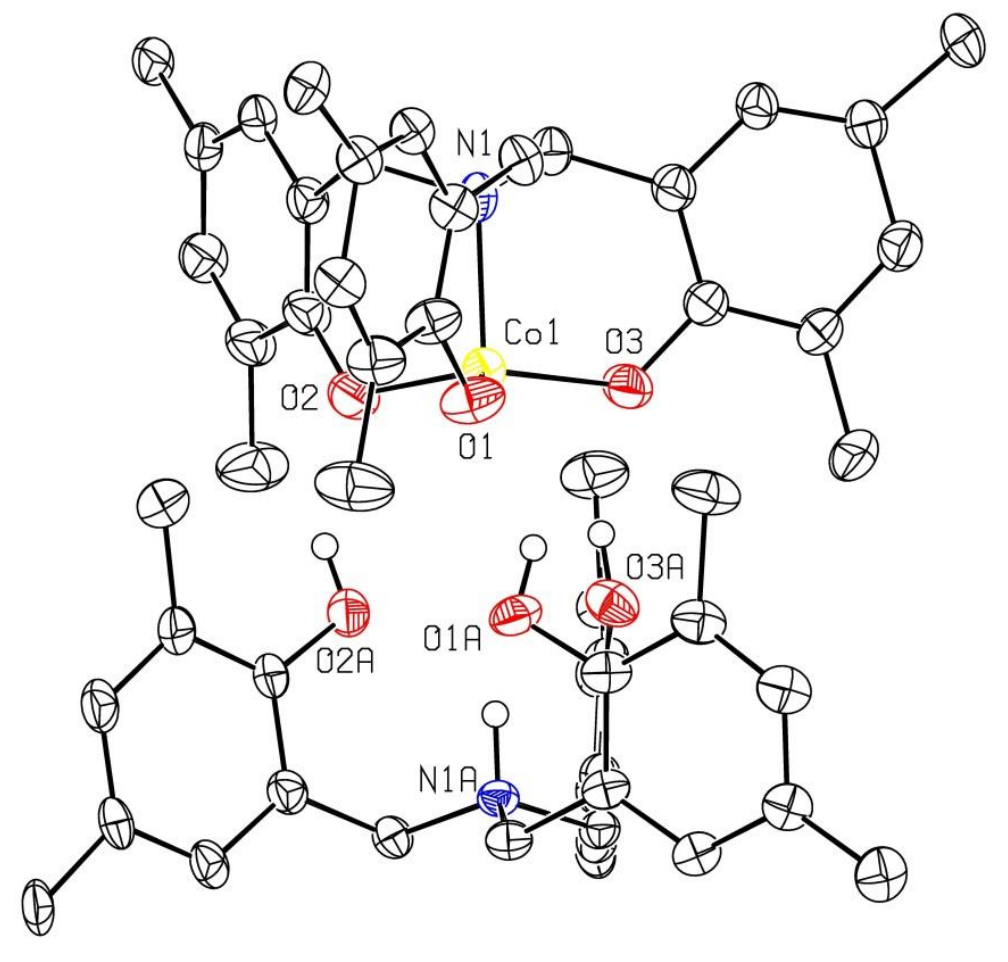

Figure 1. X-ray molecular structure for compound 5. Selected bond lengths $(\AA)$ and angles $\left(^{\circ}\right)$ : $\mathrm{Co}(1)-\mathrm{O}(1)=1.897(8), \mathrm{Co}(1)-\mathrm{O}(2)=1.904(8), \mathrm{Co}(1)-\mathrm{O}(3)=1.899(8), \mathrm{Co}(1)-\mathrm{N}(1)=2.052(10)$; $\mathrm{O}(1)-\mathrm{Co}(1)-\mathrm{N}(1)=98.9(3), \mathrm{O}(3)-\mathrm{Co}(1)-\mathrm{N}(1)=98.5(3), \mathrm{O}(2)-\mathrm{Co}(1)-\mathrm{O}(3)=117.9(4)$.

\section{RESULTS AND DISCUSSION}

To access Co-centered (ArO) ${ }_{3} \mathrm{~N}$ complexes we followed a lead from Lehtonen ${ }^{11}$ who prepared a $\mathrm{Mo}(\mathrm{VI})(\mathrm{ArO})_{3} \mathrm{~N}$ complex directly from the corresponding amino-triphenol ligand and $\mathrm{MoO}_{2}(\mathrm{acac})_{2}$. Thus, direct treatment of known ligands $\mathbf{1 - 3}{ }^{12}$ with $\mathrm{Co}(\mathrm{OAc})_{2} \cdot 4 \mathrm{H}_{2} \mathrm{O}$ was probed and furnished Co(II) complexes $\mathbf{4}$ and $\mathbf{5}$ in good yields as blue solids. ${ }^{13}$ Compounds $\mathbf{4}$ and $\mathbf{5}$ are airstable both in solution and solid phases (vide infra); both complexes crystallize conveniently from $\mathrm{MeOH}$ (4-5) and DCM (5) and their X-ray molecular structures were determined (Figure 1 and Supporting Information, Figure S39). The structure reported for compound $\mathbf{5}$ comprises of an 
anionic part viz. $\mathrm{Co}\left((\mathrm{ArO})_{3} \mathrm{~N}\right)^{-}$and a cationic $(\mathrm{ArO})_{3} \mathrm{NH}^{+}$fragment; the latter is associated to the $\mathrm{Co}(\mathrm{II})$ complex via hydrogen bonding. ${ }^{11}$ As a result, the two different hemispheres give rise to a capsular system in which the metal center sits in a mono-pyramidal coordination geometry as was also observed by Meyer and co-workers for their comparable $\mathrm{Co}(\mathrm{II})(\mathrm{ArO})_{3} \mathrm{~N}$ complexes. ${ }^{3}$ The observed structural parameters support that the Co center is tetra-coordinated and is slightly displaced from the $\mathrm{O}_{3}$-plane of the ligand towards the nitrogen center $\mathrm{N} 1$. The overall features for the anionic part of $\mathbf{5}$ closely relate to those reported for other mono-pyramidal coordination geometries reported for Co(II) complexes based on other tetra-dentate ligand systems. a $^{\text {aa, }, \mathrm{f,g}, \mathrm{g}}$

The synthetic approach towards Co(II) complexes $\mathbf{4}$ and $\mathbf{5}$ does not allow for the introduction of other cations as the aminotrisphenolate ligand $(\mathrm{ArOH})_{3} \mathrm{~N}$ itself acts as a proton scavenger. The cation $(\mathrm{ArOH})_{3} \mathrm{NH}^{+}$could also not be simply exchanged by addition of a $\mathrm{NBu}_{4} \mathrm{Cl}$ or alike in separate experiments. Therefore we probed another route towards these $\mathrm{Co}(\mathrm{II})(\mathrm{ArO})_{3} \mathrm{~N}$ complexes by first deprotonation of the $(\mathrm{ArOH})_{3} \mathrm{~N}$ ligand using $\mathrm{NaH}$ followed by transmetalation of in situ formed $(\mathrm{ArONa})_{3} \mathrm{~N}$ with $\mathrm{Co}(\mathrm{OAc})_{2}$ in THF. The product of this reaction, complex $\mathbf{6 a}$ (79\% yield, Scheme 1 and Figure 2), was isolated as a binuclear $\mathrm{Co}(\mathrm{II})$ complex that incorporates two $(\mathrm{ArO})_{3} \mathrm{~N}$ ligands, three $\mathrm{Na}$ cations, a bridging hydroxo ligand and six THF ligands. These results demonstrate that other cations may also be associated to the anionically charged $\mathrm{Co}(\mathrm{II})(\mathrm{ArO})_{3} \mathrm{~N}$ complex. The presence of a hydroxo ligand $(\mathrm{OH})$ can be explained by the presence of some $\mathrm{NaOH}$ prior, during and/or after the reaction as a result of the presence of adventitious water. We thus performed an alternative synthesis using anhydrous $\mathrm{CoCl}_{2}$ as transmetalating agent, and the addition of bis-triphenylphosphineiminium chloride ( $\mathrm{PPN}-\mathrm{Cl})$ provoked a cation exchange affording complex $\mathbf{6 b}(45 \%)$. X-ray analysis of this latter complex (Figure 3) disclosed the presence of an anionic Co(II) fragment reminiscent of complexes $\mathbf{4}$ and $\mathbf{5}$ though with an solvent 
molecule occupying the apical position and having a non-coordinating cation associated ( $\mathrm{PPN}+$ ). This result shows that, at least when isolation of the Co(II) complexes is concerned, a coordinating cation is not a prerequisite. 


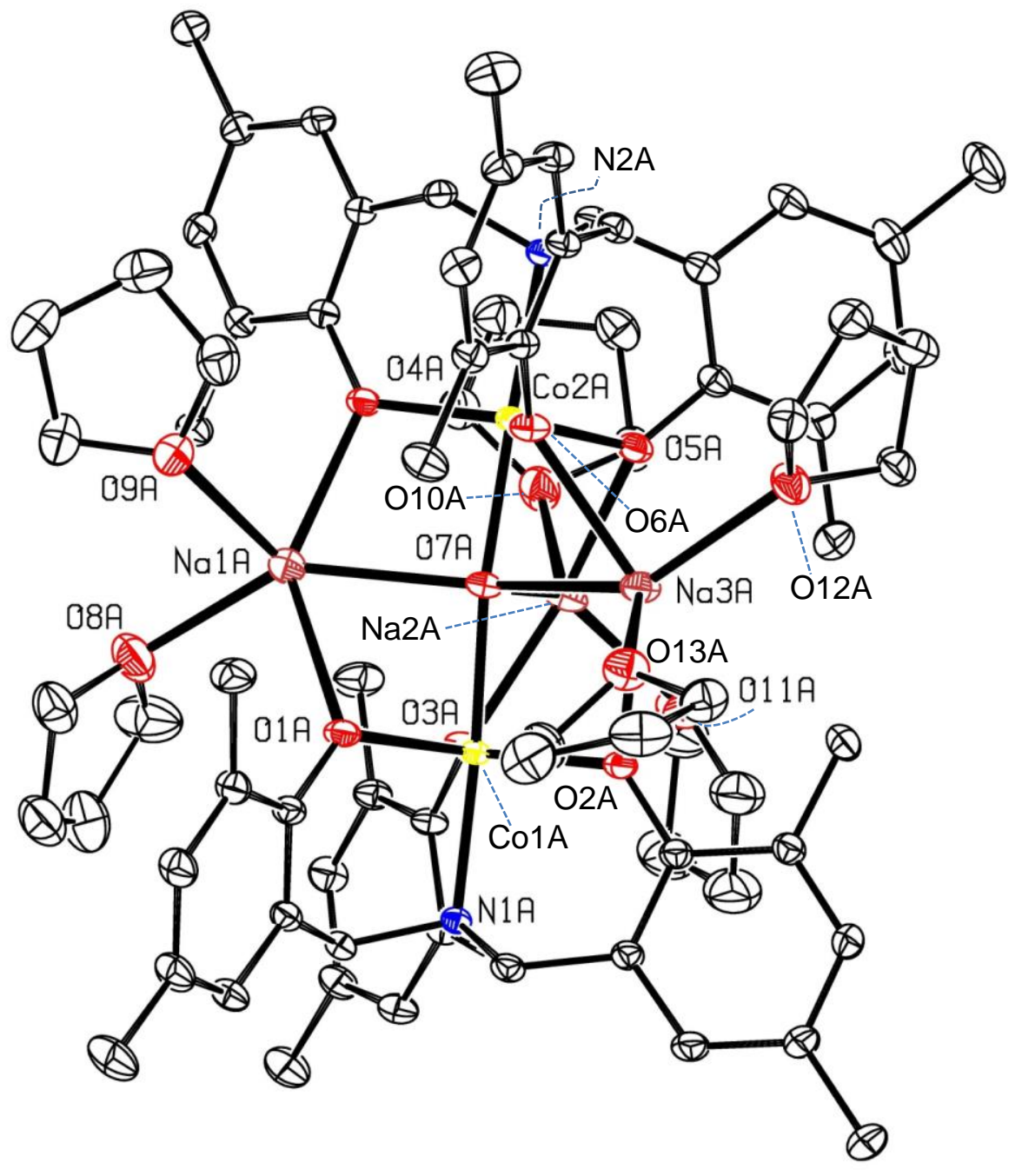

Figure 2. X-ray molecular structure for binuclear complex 6a. Selected bond lengths $(\AA \AA)$ and angles $\left({ }^{\circ}\right): \operatorname{Co}(1 \mathrm{~A})-\mathrm{O}(1 \mathrm{~A})=2.0008(14), \quad \mathrm{Co}(1 \mathrm{~A})-\mathrm{O}(2 \mathrm{~A})=1.9942(14), \quad \mathrm{Co}(1 \mathrm{~A})-\mathrm{O}(3 \mathrm{~A})=$ 1.9929(15), $\operatorname{Co}(1 \mathrm{~A})-\mathrm{N}(1 \mathrm{~A})=2.1180(19), \quad \mathrm{Co}(1 \mathrm{~A})-\mathrm{O}(7 \mathrm{~A})=2.1056(18), \quad \mathrm{Na}(1 \mathrm{~A})-\mathrm{O}(7 \mathrm{~A})=$ 2.4847(17), $\mathrm{Na}(2 \mathrm{~A})-\mathrm{O}(7 \mathrm{~A})=2.6512(19), \mathrm{Na}(3 \mathrm{~A})-\mathrm{O}(7 \mathrm{~A})=2.4335(18) ; \mathrm{O}(1 \mathrm{~A})-\mathrm{Co}(1 \mathrm{~A})-\mathrm{O}(2 \mathrm{~A})=$ 123.25(7), O(1A)-Co(1A)-O(3A) = 119.00(6), O(2A)-Co(1A)-O(3A) = 117.50(7), N(1A)$\mathrm{Co}(1 \mathrm{~A})-\mathrm{O}(7 \mathrm{~A})=175.74(6), \quad \mathrm{Co}(1 \mathrm{~A})-\mathrm{O}(7 \mathrm{~A})-\mathrm{Na}(1 \mathrm{~A})=47.68(4), \quad \mathrm{N}(1 \mathrm{~A})-\mathrm{Co}(1 \mathrm{~A})-\mathrm{O}(1 \mathrm{~A})=$ 92.03(6), $\mathrm{Na}(1 \mathrm{~A})-\mathrm{O}(7 \mathrm{~A})-\mathrm{Na}(2 \mathrm{~A})=109.44(7), \mathrm{Na}(1 \mathrm{~A})-\mathrm{O}(7 \mathrm{~A})-\mathrm{Na}(3 \mathrm{~A})=145.96(8)$. 


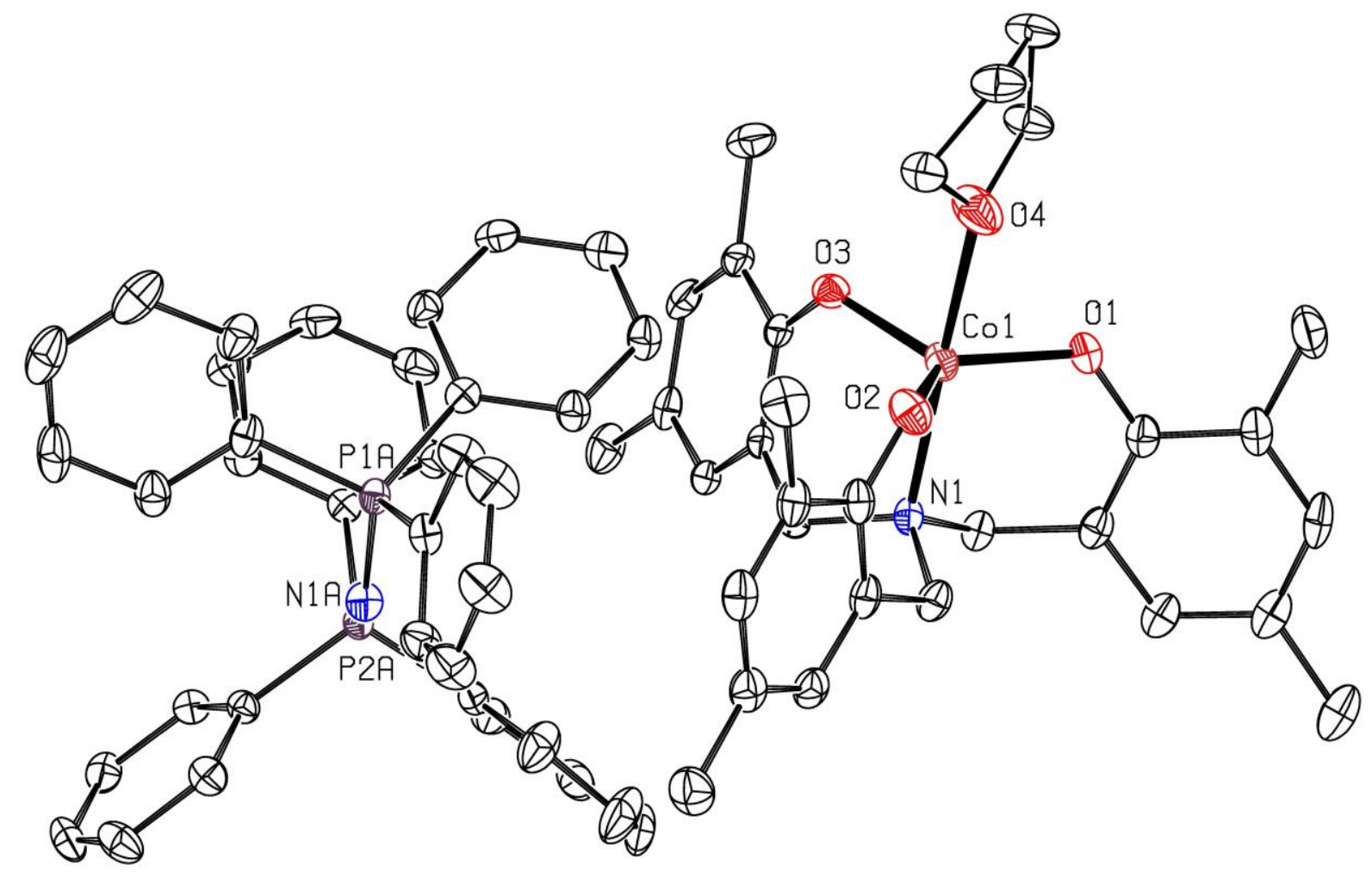

Figure 3. X-ray molecular structure for complex $\mathbf{6 b}$ together with a partial numbering scheme. Selected bond lengths $(\AA)$ and angles $\left(^{\circ}\right)$ : $\operatorname{Co}(1)-\mathrm{O}(1)=1.953(2), \operatorname{Co}(1)-\mathrm{O}(2)=1.950(2), \operatorname{Co}(1)-$ $\mathrm{O}(3)=1.949(2), \mathrm{Co}(1)-\mathrm{N}(1)=2.147(3), \mathrm{Co}(1)-\mathrm{O}(4)=2.204(6) ; \mathrm{O}(1)-\mathrm{Co}(1)-\mathrm{O}(3)=114.54(9)$, $\mathrm{O}(2)-\mathrm{Co}(1)-\mathrm{O}(3)=120.64(9), \mathrm{O}(1)-\mathrm{Co}(1)-\mathrm{O}(2)=123.92(10), \mathrm{N}(1)-\mathrm{Co}(1)-\mathrm{O}(4)=87.37(15), \mathrm{N}(1)-$ $\mathrm{Co}(1)-\mathrm{O}(1)=94.00(9) ; \mathrm{N}(1)-\mathrm{Co}(1)-\mathrm{O}(3)=92.89(9)$.

The Co(II) complexes $\mathbf{4}$ and $\mathbf{5}$ probably gain stability by steric protection exerted by the cationic unit $(\mathrm{ArO})_{3} \mathrm{NH}^{+}$that is associated to the $\mathrm{Co}(\mathrm{II})$ complex through an ionic as well as three $\mathrm{H}$-bond interactions. Further evidence for this hypothesis was gained from comparative stability studies of complexes 4 and 5, and 6b. Interestingly, while complexes $\mathbf{4}$ and $\mathbf{5}$ seem to be stable both in the solid as well as solution phase for at least $24 \mathrm{~h}$, complex $\mathbf{6 b}$ shows clear signs of decomposition in 
the solid and solution state within $24 \mathrm{~h}$ after exposure to air (see Supporting Information, Figures S50-51). Thus, it seems that the presence of an interacting, coordinating cation may help to stabilize the $\mathrm{Co}(\mathrm{II})$ oxidation state of these kinds of complexes. Cyclic voltammetry studies that involved complex $\mathbf{6 b}$ also clearly showed that oxidation is significantly more feasible for this complex as compared to complex $5\left(E_{\mathrm{p}}{ }^{\text {ox }}\right.$ is $0.27 \mathrm{~V}$ and $0.65-0.70 \mathrm{~V}$, respectively; see Supporting Information).

We decided to deprotonate compound $\mathbf{5}$ to explore the opportunity to introduce other ligands. When a solution of compound 5 in $\mathrm{CH}_{2} \mathrm{Cl}_{2}$ (blue) was treated in air ${ }^{14}$ with an excess of 4dimethylaminopyridine (DMAP) a drastic color change to dark violet was noted indicating a change in the oxidation state of the Co center and/or coordination geometry; after removal of the solvent the purple residue was re-crystallized from $\mathrm{CH}_{2} \mathrm{Cl}_{2} /$ hexane to afford complex 7 in good yield (83\%). X-ray analysis revealed the presence of a Co-complex having two DMAP ligands incorporated in the coordination sphere in complex 7 (Figure 4). The DMAP ligands occupy an equatorial and axial position of the roughly octahedral geometry around the Co center. The structure clearly demonstrates the flexibility of the $(\mathrm{ArO})_{3} \mathrm{~N}$ ligand to accommodate the formation of a hexa-coordinated complex potentially useful in catalytic conversions. ${ }^{5,6}$ 


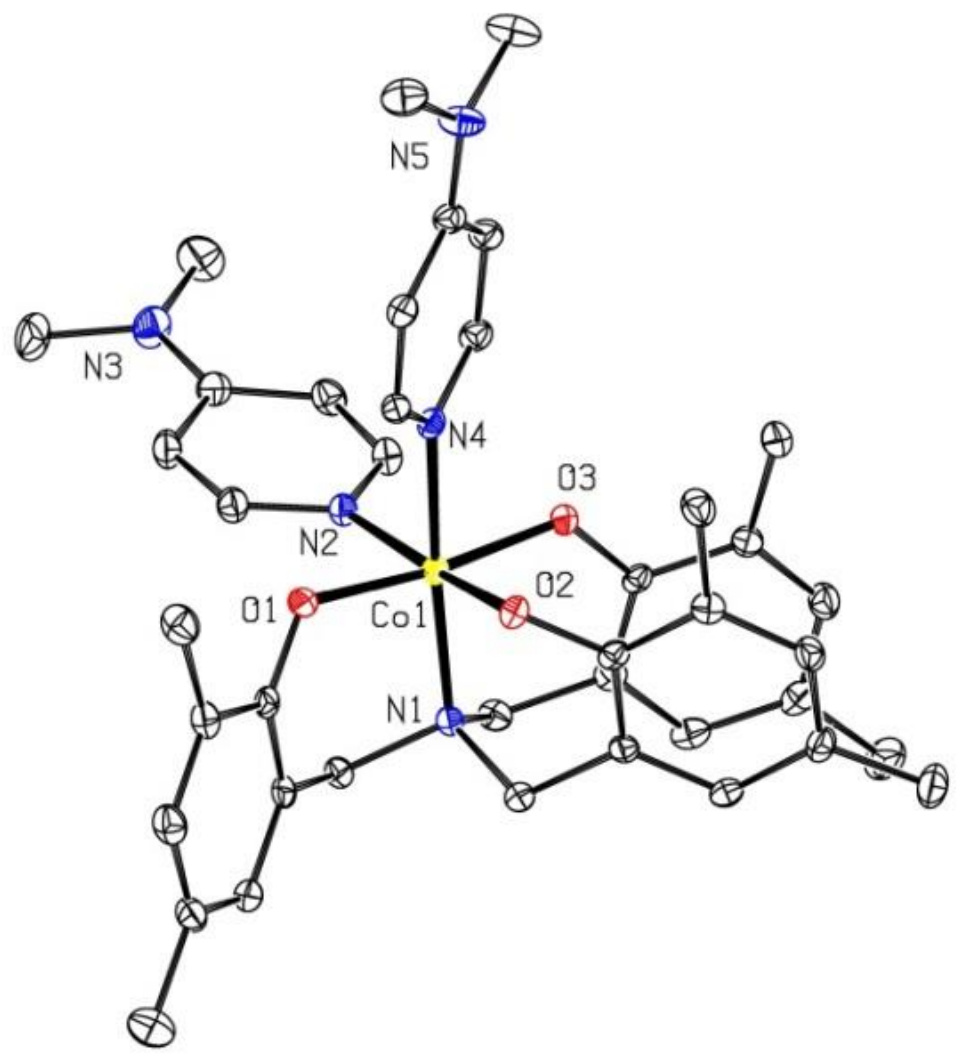

Figure 4. X-ray molecular structure for complex 7. Selected bond lengths $(\AA)$ and angles $\left(^{\circ}\right)$ : $\mathrm{Co}(1)-\mathrm{O}(1)=1.9231(13), \mathrm{Co}(1)-\mathrm{O}(2)=1.8985(14), \mathrm{Co}(1)-\mathrm{O}(3)=1.9079(13), \mathrm{Co}(1)-\mathrm{N}(1)=$ 2.0174(16), $\mathrm{Co}(1)-\mathrm{N}(2)=2.0350(17), \mathrm{Co}(1)-\mathrm{N} 4)=1.9783(16) ; \mathrm{O}(1)-\mathrm{Co}(1)-\mathrm{O}(3)=172.92(6)$, $\mathrm{N}(2)-\mathrm{Co}(1)-\mathrm{O}(2)=172.95(6), \mathrm{N}(1)-\mathrm{Co}(1)-\mathrm{N}(4)=176.23(6)$.

${ }^{1} \mathrm{H}$ NMR studies were then first performed using 5 and 7 (Supporting Information; Figures S2 and S5-8) to study their solution behavior. As expected, for 5 paramagnetically shifted resonances are found in the region -48 to $36 \mathrm{ppm}$ and no significant changes were noted upon lowering the temperature. However, for complex 7 we found that the temperature had a dramatic effect on the resolution of the ${ }^{1} \mathrm{H}$ NMR spectrum (Figure S6). At ambient conditions $\left(25^{\circ} \mathrm{C}\right)$ clearly paramagnetically induced ${ }^{1} \mathrm{H}$ NMR shifts were noted, but upon lowering the temperature to 
between -30 and $-40^{\circ} \mathrm{C}$ a fully resolved ${ }^{1} \mathrm{H}$ NMR spectrum was obtained, indicative of the sole presence of a diamagnetic complex. The ${ }^{1} \mathrm{H}$ NMR spectrum at $-40^{\circ} \mathrm{C}$ displays two down-field shifts for the DMAP-ortho hydrogens in line with the presence of two DMAP ligands in the coordination sphere of complex 7 (cf., Figure 4). We hypothesized that at higher temperatures the coordination of the DMAP ligands is fluxional leading to a paramagnetic, five-coordinate $\mathrm{Co}$ (III) complex with a trigonal pyramidal (tbp) geometry. In order to challenge this hypothesis, we prepared complex $\mathbf{8}$ as a control compound (Scheme 1); this complex bears more sterically demanding tBu groups in the ortho-positions of the phenolate donors and is likely not able to allow for hexa-coordination at the Co center. However, isolation of the Co(II) complex of ligand $\mathbf{3}$ was not feasible, and therefore we attempted the direct synthesis of $\mathbf{8}$ through combination of $\mathbf{3}$, $\mathrm{Co}(\mathrm{OAc})_{2} \cdot 4 \mathrm{H}_{2} \mathrm{O}$ and excess DMAP. An indicative color change to dark purple was noted and, fortunately, complex 8 could be conveniently isolated by re-crystallization from $\mathrm{CH}_{2} \mathrm{Cl}_{2} / \mathrm{CH}_{3} \mathrm{CN}$ (73\% yield). Crystallographic analysis showed this complex to be penta-coordinated, comprising of one DMAP ligand occupying one axial position of a tbp coordination geometry around the Co ion (Figure S40). Further to this, to block a potential dynamic behavior between penta- and hexacoordinated geometry, complex 5 was treated with a bidentate ligand (2,2'-bipyridine: 2,2'-bipy): the presence of this ligand should give rise to a structure reminiscent of complex 7 and be conformationally stable such that under ambient conditions a diamagnetic compound should prevail. Complex 9 (Scheme 1) was isolated as a brown crystalline compound (23\% yield; see Supporting Information for details) and its molecular structure was determined by X-ray diffraction (Figure S41). Complex 8 clearly displays ${ }^{1} \mathrm{H}$ NMR characteristics of a paramagnetic species at ambient and lower temperature $\left(-40^{\circ} \mathrm{C}\right.$; Figure S9), whereas the bipy-complex 9 gives rise to a well-resolved and defined ${ }^{1} \mathrm{H}$ NMR spectrum under ambient conditions (Figure S10). 
Interestingly, the presence of a bipy-ortho- $\mathrm{H}$ resonance located at $\delta=10.35$ indicates hydrogenbonding to a phenolate-O and may thus help to further stabilize this complex.

The oxidation processes for both cobalt (II) complexes (4 and 5) investigated by cyclic voltammetry are observed at relative high potential $\left(E_{\mathrm{p}}{ }^{\mathrm{ox}}=1.05\right.$ and around $0.7 \mathrm{~V}$, respectively, vs. $\mathrm{Ag} / \mathrm{AgCl}$ ) which supports a high stability of theses complexes against oxidation (Supporting Information; Figures S42-44). In the case of complex 4 a single quasi-reversible wave is observed whereas complex $\mathbf{5}$ exhibits an irreversible oxidation process as a likely result of the oxidation of the $\left(\mathrm{Ar}^{\mathrm{Me}} \mathrm{O}\right)_{3} \mathrm{~N}$ ligand. The cyclic voltammogram $(\mathrm{CV})$ for this complex showed a broad wave between $0.65-0.75 \mathrm{~V}$ vs. $\mathrm{Ag} / \mathrm{AgCl}$ due to overlapping oxidation processes that involve the $\mathrm{Co} / \mathrm{Co}{ }^{\mathrm{III}}$ redox couple within the $\left(\mathrm{Ar}^{\mathrm{Me}} \mathrm{O}\right)_{3} \mathrm{~N}$ ligand, and the $\left(\mathrm{Ar}^{\mathrm{Me}} \mathrm{O}\right)_{3} \mathrm{NH}^{+}$cationic unit. The $\mathrm{CV}$ obtained for cobalt (III) complex $\mathbf{7}$ displays, under these conditions, a reversible reduction process at $E_{1 / 2}=-0.09 \mathrm{~V}$ vs. $\mathrm{Ag} / \mathrm{AgCl}$ attributed to the $\mathrm{Co}{ }^{\mathrm{III}} / \mathrm{Co}^{\mathrm{II}}$ couple (Figure S47) and cobalt (III) compounds $\mathbf{8}$ and 9 give rise to similar quasi-reversible $\mathrm{CV}$ s for the $\mathrm{Co}$ III $/ \mathrm{Co}^{\mathrm{II}}$ couple at $E_{1 / 2}=-0.13$ and $-0.05 \mathrm{~V}$ respectively vs. $\mathrm{Ag} / \mathrm{AgCl}$ (Figures S48-49). From these data it seems that the DMAP ligands in complex 7 are effective in the stabilization of the $\mathrm{Co}^{\mathrm{III}}$ oxidation state, whereas $\left(\mathrm{Ar}^{\mathrm{Me}} \mathrm{O}\right)_{3} \mathrm{NH}^{+}$cation in complexes $\mathbf{4}$ and $\mathbf{5}$ is able to protect the $\mathrm{Co}^{\mathrm{II}}$ from low-potential oxidation. Finally, we performed magnetic susceptibility measurements in polycrystalline samples of 4,5 and 7-9 (Figure 5). The $\chi \mathrm{mT}$ products at room temperature are $2.25,2.79,-0.11,1.28$ and -0.26 emu K mol ${ }^{-1}$, respectively. These values correspond to a $S=3 / 2$ with strong spin-orbit coupling, as expected for high spin $\mathrm{Co}(\mathrm{II})$ in $\mathbf{4}$ and $\mathbf{5}$; a diamagnetic $S=0$, from the octahedral low spin Co(III) in 7 and 9; and a $S=1$, from the two unpaired electrons expected in a Co(III) center with tbp coordination in $\mathbf{8} .{ }^{15}$ These are in good agreement with the NMR data. The temperature dependence of the magnetization is dominated by the zero-field splitting of the single ions. 
From the room temperature values, $\chi_{\mathrm{m}} \mathrm{T}$ decreases as temperature is decreased for the paramagnetic complexes 4,5 and 8 . In the case of $4, \chi_{\mathrm{m}} \mathrm{T}$ remains constant at $2.25 \mathrm{emu} \mathrm{K} \mathrm{mol}^{-1}$ down to $60 \mathrm{~K}$, when it drops fast down to $1.0 \mathrm{emu} \mathrm{K} \mathrm{mol}^{-1}$ at $2 \mathrm{~K}$. In the case of $5, \chi_{\mathrm{m}} \mathrm{T}$ decreases slowly from 2.79 down to $2.30 \mathrm{emu} \mathrm{K} \mathrm{mol}{ }^{-1}$ at $50 \mathrm{~K}$, and then it drops fast down to $1.5 \mathrm{emu} \mathrm{K}$ $\mathrm{mol}^{-1}$ at $2 \mathrm{~K}$. This behavior in $\mathbf{4}$ and $\mathbf{5}$ is typical of high spin trigonal pyramidal Co(II) complexes, with strong spin orbit coupling, analogous to that reported by Meyer for related Co(II) species. ${ }^{3}$ In the case of $\mathbf{8}, \chi_{\mathrm{m}} \mathrm{T}$ remains essentially constant down to $80 \mathrm{~K}$, and then it also drops sharply reaching $0.10 \mathrm{emu} \mathrm{K} \mathrm{mol}{ }^{-1}$ at $2 \mathrm{~K}$, due to the zero-field splitting of the triplet ground state. Complexes $\mathbf{7}$ and $\mathbf{9}$ are diamagnetic at room temperature. As the temperature is decreased, $\chi_{\mathrm{m}} \mathrm{T}$ shows a linear behavior, approaching positive values. This must be due to the presence of paramagnetic impurities that represent less than $3 \%$ of the complexes.

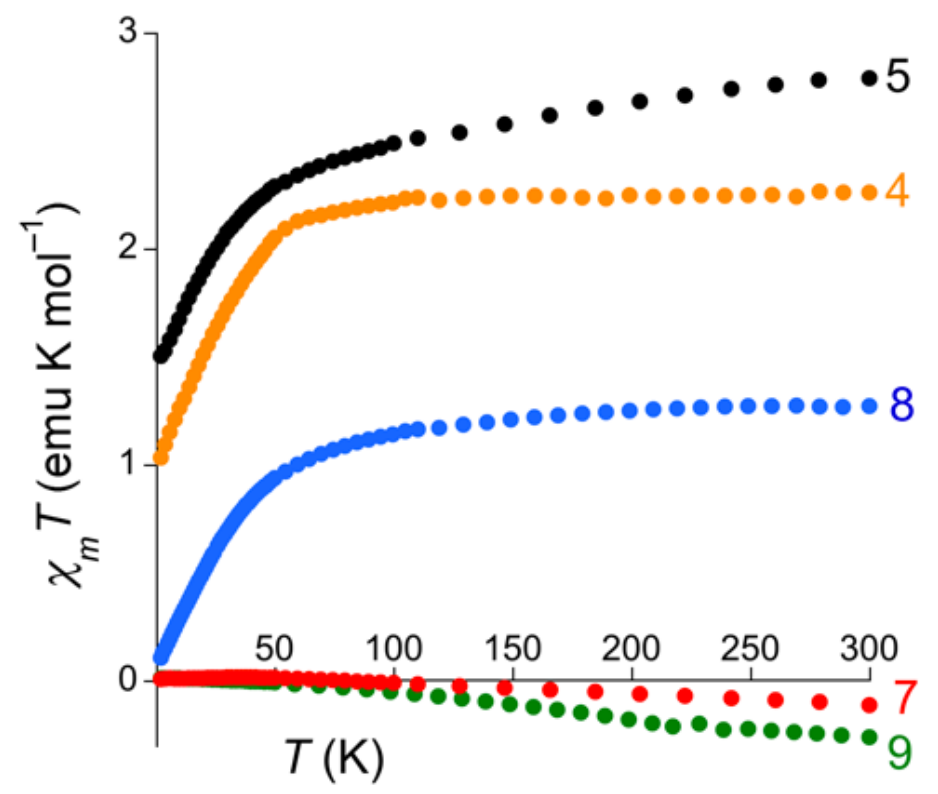

Figure 5. Temperature dependence of the $\chi_{\mathrm{m}} \mathrm{T}$ product for complexes 4,5 and 7-9. 


\section{CONCLUSION}

In summary, we here present an easy route towards $\mathrm{Co}(\mathrm{III})(\mathrm{ArO})_{3} \mathrm{~N}$ complexes and their full characterization using a variety of analytical techniques. The straightforward dependence of the coordination geometry around the Co ion on the ligand substitution in these complexes allows for penta- and/or hexacoordinated metal centers. In the hexacoordinated Co(III) complexes 7 and 9 the presence of two cis-positioned N-donor ligands suggests that these complexes may be of value in catalytic transformations such as the co-polymerization of epoxides and $\mathrm{CO}_{2}$. However, this may be true only when suitable ligands or substrates are involved that can facilitate the oxidation of the $\mathrm{Co}(\mathrm{II})$ complex. The catalytic $\mathrm{CO}_{2}$ /epoxide coupling reactions are currently under investigation.

\section{- EXPERIMENTAL SECTION}

General Considerations. All reagents were purchased from commercial suppliers and used as received. All solvents were of reagent grade and use without any further purification. The ligands $\mathrm{H}_{3} \mathrm{~L}^{\mathrm{H}}, \mathrm{H}_{3} \mathrm{~L}^{\mathrm{Me}}, \mathrm{H}_{3} \mathrm{~L}^{\mathrm{tBu}}$ (compounds 1-3) were prepared according to literature methods. ${ }^{12,16}$ Elemental Analysis was performed by the Unidád de Análisis Elemental at the Universidad de Santiago de Compostela (Spain). Mass spectrometric analyses and X-ray diffraction studies were carried out by the Research Support Group at the ICIQ. FT-IR measurements were performed on a Bruker Optics FTIR Alpha spectrometer equipped with a DTGS detector, KBr beam-splitter at $4 \mathrm{~cm}^{-1}$ resolution. UV-Vis measurements were carried out on a Shimadzu UV-2401PC spectrophotometer equipped with a photomultiplier detector, double beam optics, and D2 and W light sources. NMR spectra were recorded on a Bruker AV-400 or AV-500 spectrometer and referenced to the residual NMR solvent signals. 
Synthesis of $\left[\left(\mathrm{Ar}^{\mathrm{H}} \mathrm{O}\right)_{3} \mathrm{NCo}^{-}\left[\left(\mathrm{Ar}^{\mathrm{H}} \mathrm{OH}\right)_{3} \mathrm{NH}\right]^{+}\right.$, complex (4): To a solution of the ligand tris(2hydroxybenzyl)amine $\left(\mathrm{Ar}^{\mathrm{H}} \mathrm{OH}\right)_{3} \mathrm{~N} 1(201.0 \mathrm{mg}, 0.6 \mathrm{mmol}, 2$ equiv.) in methanol $(10 \mathrm{~mL})$ was added a solution of $\mathrm{Co}(\mathrm{OAc})_{2} \cdot 4 \mathrm{H}_{2} \mathrm{O}(77.0 \mathrm{mg}, 0.3 \mathrm{mmol}, 1$ equiv. $)$ in methanol $(10 \mathrm{~mL})$. The mixture was stirred at r.t. and after $1 \mathrm{~h}$ a crystalline blue solid precipitated. The blue complex was filtrated, washed with methanol and dried. Yield: $145.7 \mathrm{mg}(0.19 \mathrm{mmol}, 62 \%)$. The crystalline complex 4 thus obtained from the reaction described above was suitable for X-ray crystallographic analysis. ${ }^{1} \mathrm{H} \mathrm{NMR}\left(\mathrm{CDCl}_{3}, 400 \mathrm{MHz}, \mathrm{RT}\right)$ : paramagnetic spectrum, $\delta=32.46,16.35,10.00,6.52$, 4.73, $1.33,-8.98,-12.89,-43.30 ; \operatorname{MALDI}(+)-\mathrm{MS}(\mathrm{dctb}): m / z=336.2\left[\left(\mathrm{Ar}^{\mathrm{H}} \mathrm{OH}\right)_{3} \mathrm{NH}\right]^{+}(\mathrm{calcd}$. 336.2), MALDI(-)-MS (dctb): $m / z=391\left[\left(\mathrm{Ar}^{\mathrm{H}} \mathrm{O}\right)_{3} \mathrm{NCo}\right]^{-}$(calcd. 391). Anal. calcd. for $\mathrm{C}_{42} \mathrm{H}_{40} \mathrm{CoN}_{2} \mathrm{O}_{6} \cdot \mathrm{MeOH}: \mathrm{C} 67.98, \mathrm{H}$ 5.84, N 3.69; found: C 68.03, H 5.62, N 3.86. IR ( $\left.\mathrm{cm}^{-1}\right): 1593$, $1478,1456,1265,1248,879,751,731,596,568,479 ; \mathrm{UV} / \mathrm{Vis}\left(\mathrm{CH}_{2} \mathrm{Cl}_{2}, 0.2 \mathrm{mM}, 25^{\circ} \mathrm{C}, \varepsilon=\mathrm{L} \cdot \mathrm{mol}^{-}\right.$ $\left.{ }^{1} \cdot \mathrm{cm}^{-1}\right): 338 \mathrm{~nm}(155), 572 \mathrm{~nm}(230), 606 \mathrm{~nm}(260), 624 \mathrm{~nm}(225)$.

Synthesis of $\left[\left(\mathrm{Ar}^{\mathrm{Me}} \mathrm{O}\right)_{3} \mathrm{NCo}\right]^{-}\left[\left(\mathrm{Ar}^{\mathrm{Me}} \mathrm{OH}\right)_{3} \mathrm{NH}\right]^{+}$, complex (5): To a solution of the ligand tris(2-hydroxy-4,6-dimethylbenzyl)amine $\left(\mathrm{Ar}^{\mathrm{Me}} \mathrm{OH}\right)_{3} \mathrm{~N} 2(419.0 \mathrm{mg}, 1.0 \mathrm{mmol}, 2$ equiv.) in methanol $(15 \mathrm{~mL})$ was added a solution of $\mathrm{Co}(\mathrm{OAc})_{2} \cdot 4 \mathrm{H}_{2} \mathrm{O}(124.0 \mathrm{mg}, 0.5 \mathrm{mmol}, 1$ equiv. $)$ in methanol $(15 \mathrm{~mL})$. The mixture was stirred at r.t. and after $1 \mathrm{~h}$ a blue solid precipitated. The blue complex was filtrated, washed with methanol and dried. Yield: $375.5 \mathrm{mg}(0.4 \mathrm{mmol}, 84 \%)$. Crystals suitable for X-ray crystallographic analysis were obtained by diffusing hexane into a solution of $\mathbf{1}$ in dichloromethane. The sample for microanalysis was crystallized from $\mathrm{MeOH} .{ }^{1} \mathrm{H}$ NMR $\left(\mathrm{CD}_{2} \mathrm{Cl}_{2}, 500 \mathrm{MHz}, \mathrm{RT}\right)$ : paramagnetic spectrum, $\delta=35.65,27.11,25.14,9.30,6.15,3.46$, $1.78,1.53,0.88,-7.80,-11.10,-48.45 ; \operatorname{MALDI}(+)-\mathrm{MS}(\mathrm{dctb}): \mathrm{m} / \mathrm{z}=420.5\left[\left(\mathrm{Ar}^{\mathrm{Me}} \mathrm{OH}\right)_{3} \mathrm{NH}\right]^{+}$ (calcd. 420.3), MALDI(-)-MS (dctb): $m / z=475.1\left[\left(\mathrm{Ar}^{\mathrm{Me}} \mathrm{O}\right)_{3} \mathrm{NCo}^{-}\right.$(calcd. 475.2). Anal. calcd. for $\mathrm{C}_{54} \mathrm{H}_{64} \mathrm{CoN}_{2} \mathrm{O}_{6} \cdot 1.5 \mathrm{MeOH}$ : C 70.61, H 7.47, N 2.97; found: C 70.59, H 7.52, N 2.95. IR $\left(\mathrm{cm}^{-1}\right)$ : 
2916, 2856, 1494, 1474, 1436, 1254, 1208, 1161, 860, 800, 615, 473 (m); UV/Vis $\left(\mathrm{CH}_{2} \mathrm{Cl}_{2}, 0.2\right.$

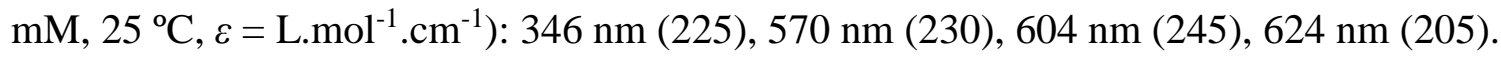

Synthesis of $\left[\left(\mathrm{Ar}^{\mathrm{Me}} \mathrm{O}\right)_{3} \mathrm{NCo}\right]_{2}(\mathrm{OH})(\mathrm{Na})_{3}(\mathrm{thf})_{6}$, complex $(6 \mathrm{a})$ : A suspension of sodium hydride (64.0 mg, $2.7 \mathrm{mmol}, 3.5$ equiv.) in $15 \mathrm{~mL}$ of tetrahydrofurane was added dropwise into a Schlenk flask containing a solution of tris(2-hydroxy-4,6-dimethylbenzyl)amine $\left(\mathrm{Ar}^{\mathrm{Me}} \mathrm{OH}\right)_{3} \mathrm{~N}$ ligand (314.0 mg, $0.75 \mathrm{mmol}, 1$ equiv.) in $15 \mathrm{~mL}$ of tetrahydrofurane. The mixture was stirred at r.t. for $2 \mathrm{~h}$ and then it was added into a Schelenk flask containing $\mathrm{Co}(\mathrm{OAc})_{2} .4 \mathrm{H}_{2} \mathrm{O}(186.0 \mathrm{mg}, 0.75 \mathrm{mmol}$, 1 equiv.). After $12 \mathrm{~h}$ stirring at r.t. the solution was filtered through celite and complexes were obtained as crystalline solids at r.t. by concentration of the solution. Yield: $305.0 \mathrm{mg}(0.29 \mathrm{mmol}$, $79 \%) .{ }^{1} \mathrm{H} \mathrm{NMR}\left(\mathrm{CDCl}_{3}, 400 \mathrm{MHz}, \mathrm{RT}\right)$ : paramagnetic spectrum, $\delta=36.10,30.11,22.65,6.39$, 3.69, 1.96, 1.77, 1.12, 0.34. MALDI(-)-HRMS (dctb): $\mathrm{m} / z=1013.2902[\mathrm{M}-\mathrm{Na}]^{-}($calcd. 1013.2938), Anal. calcd. for $\mathrm{C}_{54} \mathrm{H}_{61} \mathrm{Co}_{2} \mathrm{~N}_{2} \mathrm{Na}_{3} \mathrm{O}_{7} \cdot(\text { thf })_{2}$ : C 63.05, H 6.57, N 2.37; found: C 62.55, H 7.03, N 2.28. IR (cm $\left.{ }^{-1}\right): 2962,2907,1259,1086,1016,796 ; \mathrm{UV} / \mathrm{Vis}\left(\mathrm{CH}_{2} \mathrm{Cl}_{2}, 0.4 \mathrm{mM}, 25^{\circ} \mathrm{C}, \varepsilon\right.$ $\left.=\mathrm{L} \cdot \mathrm{mol}^{-1} \cdot \mathrm{cm}^{-1}\right): 398 \mathrm{~nm}(4940), 490 \mathrm{~nm}(3200), 698(695), 1032(475)$.

Synthesis of $\left[\left(\mathrm{Ar}^{\mathrm{Me}} \mathrm{O}\right)_{3} \mathrm{NCo}\right]^{-}[\mathrm{PPN}]^{+}$, complex (6b): A suspension of sodium hydride (53.0 $\mathrm{mg}, 2.2 \mathrm{mmol}, 3$ equiv.) in $10 \mathrm{~mL}$ of tetrahydrofuran was added drop-wise into a Schlenk flask containing a solution of tris(2-hydroxy-4,6-dimethylbenzyl)amine $\left(\mathrm{Ar}^{\mathrm{Me}} \mathrm{OH}\right)_{3} \mathrm{~N}$ ligand $(300.0 \mathrm{mg}$, $0.72 \mathrm{mmol}, 1$ equiv.) in $10 \mathrm{~mL}$ of tetrahydrofuran. The mixture was stirred at room temperature for $2 \mathrm{~h}$. After this time, 0.95 equiv. of anhydrous $\mathrm{CoCl}_{2}(88.0 \mathrm{mg}, 0.68 \mathrm{mmol})$ in $10 \mathrm{~mL}$ of acetonitrile was added. The reaction mixture was stirred at r.t. for $18 \mathrm{~h}$ and then it was filtered through a path of Celite. The solution obtained was added into a Schlenk flask containing 1 equiv. of bis(triphenylphosphine)iminium chloride, $\mathrm{PPN}-\mathrm{Cl},(0.7 \mathrm{mmol}, 402 \mathrm{mg})$ to exchange the cation. After $6 \mathrm{~h}$, the mixture was filtered through a path of Celite. The complex was obtained as a 
crystalline solid suitable for X-ray crystallographic analysis by concentration of the solution and by addition of hexane (v/v = 1:1). Yield: $335.0 \mathrm{mg}(0.14 \mathrm{mmol}, 45 \%) .{ }^{1} \mathrm{H} \mathrm{NMR}\left(\mathrm{CD}_{2} \mathrm{Cl}_{2}, 400\right.$ MHz, RT): paramagnetic spectrum, $\delta=37.82,28.56,27.89,7.51,7.36,3.55,1.89,1.70,-7.79$, -

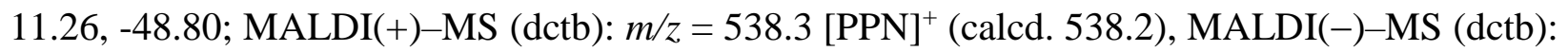
$m / z=475.1563 \quad\left[\left(\mathrm{Ar}^{\mathrm{Me}} \mathrm{O}\right)_{3} \mathrm{NCo}\right]^{-} \quad($ calcd. 475.1559). Anal. calcd. for $\mathrm{C}_{63} \mathrm{H}_{60} \mathrm{CoN}_{2} \mathrm{O}_{3} \mathrm{P}_{2} \cdot$ thf. $1 / 2 \mathrm{CH}_{3} \mathrm{CN} \cdot 2 \mathrm{H}_{2} \mathrm{O}$ : C 71.91, H 6.84, N 2.95; found: C 71.65, H 6.69, N 2.84. The presence of both solvents (thf and $\mathrm{CH}_{3} \mathrm{CN}$ ) and their 2:1 ratio is supported by ${ }^{1} \mathrm{H} \mathrm{NMR}$ of the dried isolated complex, see Supporting Information. IR $\left(\mathrm{cm}^{-1}\right): 3056,2962,2913,2859,1608$, $1588,1480,1469,1435,1358,1308,1244,1183,1161,1113,1060,1027,997,904,860,801$, 749, 721, 690, 605, 549, 532, 495,423; UV/Vis $\left(\mathrm{CH}_{2} \mathrm{Cl}_{2}, 0.2 \mathrm{mM}, 25^{\circ} \mathrm{C}, \varepsilon=\mathrm{L} \cdot \mathrm{mol}^{-1} \cdot \mathrm{cm}^{-1}\right): 348$ $\mathrm{nm}$ (725), $580 \mathrm{~nm}(330), 605 \mathrm{~nm}(335), 622 \mathrm{~nm}(325)$.

Synthesis of $\left(\mathrm{Ar}^{\mathrm{Me}} \mathrm{O}\right)_{3} \mathrm{NCo}(\mathrm{DMAP})_{2}$, complex (7): A solution of 4-dimethylaminopyridine (DMAP) in $10 \mathrm{~mL}$ of dichloromethane (102.5 mg, $0.84 \mathrm{mmol}, 2.5$ equiv.) was added to a round bottom flask containing a blue solution of complex 5 (300.0 mg, $0.34 \mathrm{mmol}, 1$ equiv.) in dichloromethane $(10 \mathrm{~mL})$. The mixture was stirred in the presence of air at r.t. for $8 \mathrm{~h}$. Then the solvent was removed to give a purple residue. The resulting compound was recrystallized from a mixture of dichloromethane/hexane (1:1 v/v) to give purple crystals. Yield: $200.0 \mathrm{mg}(0.28 \mathrm{mmol}$, $83 \%$ ). Synthesis in an inert atmosphere (either $\mathrm{N}_{2}$ or argon) under similar conditions yields $17 \%$ of the $\mathrm{Co}$ (III) complex 7. ${ }^{1} \mathrm{H} \mathrm{NMR}\left(\mathrm{CD}_{2} \mathrm{Cl}_{2}, 500 \mathrm{MHz}, \mathrm{RT}\right)$ : paramagnetic spectrum, $\delta=54.94$, 48.74, 41.09, 25.42, 8.24, 6.51, 3.00, 1.71, 1.26, -10.61, -53.61; ${ }^{1} \mathrm{H} \mathrm{NMR}\left(\mathrm{CD}_{2} \mathrm{Cl}_{2}, 500 \mathrm{MHz}, 233\right.$ $\mathrm{K})$ : diamagnetic spectrum, $\delta=8.53\left(\mathrm{~d},{ }^{3} \mathrm{~J}=6.0 \mathrm{~Hz}, 2 \mathrm{H}, \mathrm{C} H_{\mathrm{pyr}}\right), 8.13\left(\mathrm{~d},{ }^{3} \mathrm{~J}=6.0 \mathrm{~Hz}, 2 \mathrm{H}, \mathrm{C} H_{\text {pyr }}\right)$, $6.61\left(\mathrm{~d},{ }^{3} \mathrm{~J}=6.0 \mathrm{~Hz}, 2 \mathrm{H}, \mathrm{C} H_{\mathrm{pyr}}\right), 6.54(\mathrm{~s}, 2 \mathrm{H}, \mathrm{CH}$ Ar $), 6.52\left(\mathrm{~s}, 2 \mathrm{H}, \mathrm{CH} H_{\mathrm{Ar}}\right), 6.38\left(\mathrm{~d},{ }^{3} J=6.0 \mathrm{~Hz}, 2 \mathrm{H}\right.$, $\left.\mathrm{CH}_{\mathrm{pyr}}\right), 6.12\left(\mathrm{~s}, 1 \mathrm{H}, \mathrm{CH} H_{\mathrm{Ar}}\right), 5.84\left(\mathrm{~s}, 1 \mathrm{H}, \mathrm{CH} H_{\mathrm{Ar}}\right), 4.13\left(\mathrm{~d},{ }^{2} \mathrm{~J}=12.0 \mathrm{~Hz}, 2 \mathrm{H}, \mathrm{ArCH}_{2} \mathrm{~N}\right), 3.08(\mathrm{~s}, 6 \mathrm{H}$, 
$\left.\mathrm{NCH}_{3}\right), 3.01\left(\mathrm{~s} \mathrm{br}, 2 \mathrm{H}, \mathrm{ArCH}_{2} \mathrm{~N}\right), 2.94\left(\mathrm{~s}, 6 \mathrm{H}, \mathrm{NCH}_{3}\right), 2.86\left(\mathrm{~d},{ }^{2} J=12.0 \mathrm{~Hz}, 2 \mathrm{H}, \mathrm{ArCH}_{2} \mathrm{~N}\right), 2.11$ (s, 6H, $\left.\mathrm{ArCH}_{3}\right), 2.02\left(\mathrm{~s}, 6 \mathrm{H}, \mathrm{ArCH}_{3}\right), 1.68\left(\mathrm{~s}, 3 \mathrm{H}, \mathrm{ArCH}_{3}\right), 1.53\left(\mathrm{~s}, 3 \mathrm{H}, \mathrm{ArCH}_{3}\right) ;{ }^{13} \mathrm{C}\left\{{ }^{1} \mathrm{H}\right\} \mathrm{NMR}$ $\left(\mathrm{CD}_{2} \mathrm{Cl}_{2}, 126 \mathrm{MHz}, 233 \mathrm{~K}\right): \delta=160.5\left(C_{\mathrm{q}}\right), 159.5\left(C_{\mathrm{q}}\right), 154.3\left(C_{\mathrm{q}}\right), 154.1\left(C_{\mathrm{q}}\right), 150.5\left(C_{\mathrm{pyr}}\right)$, $150.1\left(\mathrm{CH}_{\mathrm{pyr}}\right), 130.6\left(C \mathrm{H}_{\mathrm{Ar}}\right), 130.0\left(C_{\mathrm{q}}\right), 129.8\left(C_{\mathrm{q}}\right), 129.1\left(C \mathrm{H}_{\mathrm{Ar}}\right), 128.7\left(C_{\mathrm{q}}\right), 127.4\left(C \mathrm{H}_{\mathrm{Ar}}\right), 126.9$ $\left(\mathrm{CH}_{\mathrm{Ar}}\right), 123.3\left(C_{\mathrm{q}}\right), 121.1\left(C_{\mathrm{q}}\right), 120.4\left(C_{\mathrm{q}}\right), 107.0\left(\mathrm{CH}_{\mathrm{pyr}}\right), 105.2\left(\mathrm{CH}_{\mathrm{pyr}}\right), 66.0\left(\mathrm{ArCH}_{2} \mathrm{~N}\right), 61.2$ $\left(\mathrm{ArCH}_{2} \mathrm{~N}\right), 39.4\left(\mathrm{NCH}_{3}\right), 39.3\left(\mathrm{NCH}_{3}\right), 20.6\left(\mathrm{ArCH}_{3}\right), 20.3\left(\mathrm{ArCH}_{3}\right), 17.8\left(\mathrm{ArCH}_{3}\right), 17.1\left(\mathrm{ArCH}_{3}\right)$; $\mathrm{ESI}(+)-\mathrm{MS}\left(\mathrm{CH}_{3} \mathrm{CN}\right): \mathrm{m} / z=720.2[\mathrm{M}+\mathrm{H}]^{+}($calcd. 720.3$), 598.2[\mathrm{M}-\mathrm{DMAP}+\mathrm{H}]^{+}($calcd. 598.2), $476.1[\mathrm{M}-2 \mathrm{DMAP}+\mathrm{H}]^{+}$(calcd. 476.2); Anal. calcd. for $\mathrm{C}_{41} \mathrm{H}_{50} \mathrm{CoN}_{5} \mathrm{O}_{3} \cdot 2 \mathrm{H}_{2} \mathrm{O}: \mathrm{C} 65.15, \mathrm{H} 7.20, \mathrm{~N}$ 9.27; found: C 64.90, H 7.02, N 9.13. IR $\left(\mathrm{cm}^{-1}\right)$ : 2983, 2904, 2852, 1614, 1530, 1469, 1440, 1383, $1271,1219,1009,949,806,736,499,428(\mathrm{~m}) ; \mathrm{UV} / \mathrm{Vis}\left(\mathrm{CH}_{2} \mathrm{Cl}_{2}, 0.2 \mathrm{mM}, 25^{\circ} \mathrm{C}, \varepsilon=\mathrm{L} \cdot \mathrm{mol}^{-1} \cdot \mathrm{cm}^{-}\right.$ $\left.{ }^{1}\right): 330 \mathrm{~nm}(7560), 532 \mathrm{~nm}(5650), 894 \mathrm{~nm}(510)$.

Synthesis of $\left(\mathrm{Ar}^{\mathrm{tBu}} \mathrm{O}\right)_{3} \mathbf{N C o}(\mathrm{DMAP})$, complex (8): To a Schlenk flask containing a pink solution of $\mathrm{Co}(\mathrm{OAc})_{2} \cdot \mathrm{H}_{2} \mathrm{O}(223.0 \mathrm{mg}, 0.9 \mathrm{mmol}, 1$ equiv $)$ in $\mathrm{MeOH}(10 \mathrm{~mL})$ was added a colorless solution of tris(2-hydroxy-4,6-di-tert-buthylbenzyl)amine $\left(\mathrm{Ar}^{\mathrm{tBu}} \mathrm{OH}\right)_{3} \mathrm{~N}$ ligand $(600.0 \mathrm{mg}, 0.9$ mmol, 1 equiv.) in tetrahydrofuran $(15 \mathrm{~mL})$. The reaction was then stirred at r.t. for $2 \mathrm{~h}$. After this a solution of dimethylaminpyridine (DMAP) in $10 \mathrm{~mL}$ of tetrahydrofuran ( $244.0 \mathrm{mg}, 2 \mathrm{mmol}, 2.5$ equiv.) was added to the flask. This mixture was further stirred open to the air at r.t. overnight. Finally, the solvent was removed to obtain a purple residue. The resulting cobalt complex was purified by recrystallization using a mixture of dichloromethane/acetonitrile in a proportion 1:1 to yield purple crystals. Yield: $550.0 \mathrm{mg}(0.65 \mathrm{mmol}, 73 \%) .{ }^{1} \mathrm{H} \mathrm{NMR}\left(\mathrm{CD}_{2} \mathrm{Cl}_{2}, 500 \mathrm{MHz}, \mathrm{RT}\right)$ : paramagnetic spectrum, $\delta=49.50,26.60,4.98,2.76,1.58,1.42,1.31,0.96,-9.12,-45.25$; MALDI(+)-MS (dctb): $m / z=849.9\left[^{[M}\right]^{+}\left(\right.$calcd. 849.5), 727.7 [M-DMAP] $^{+.}($calcd. $727.4 ;$ cf. Figure S32), 672.7 [M-DMAP-tBu+H $]^{+}$(calcd. 672.4; cf. Figure S32); Anal. calcd. for 
$\mathrm{C}_{52} \mathrm{H}_{76} \mathrm{CoN}_{3} \mathrm{O}_{3} \cdot 1 / 2 \mathrm{H}_{2} \mathrm{O}: \mathrm{C} 72.70, \mathrm{H}$ 9.03, N 4.89; found: C 72.66, H 9.31, N 4.98. IR (cm $\left.{ }^{-1}\right): 2951$, 2903, 2865, 1620, 1536, 1458, 1443, 1412, 1383, 1361, 1263, 1220, 1171, 1022, 874, 834, 808, 624, 548, 536, 469 (m); UV/Vis $\left(\mathrm{CH}_{2} \mathrm{Cl}_{2}, 0.2 \mathrm{mM}, 25^{\circ} \mathrm{C}, \varepsilon=\mathrm{L} \cdot \mathrm{mol}^{-1} \cdot \mathrm{cm}^{-1}\right): 334 \mathrm{~nm}(9425), 536$ $\mathrm{nm}$ (7550), $926 \mathrm{~nm}(795)$.

Synthesis of (Ar $\left.{ }^{\mathrm{Me}} \mathbf{O}\right)_{3} \mathbf{N C o}($ bipy), complex (9): A solution of 2,2'-bipyridine (bipy) in $10 \mathrm{~mL}$ of dichloromethane (183.0 mg, $1.17 \mathrm{mmol}, 5.3$ equiv.) was added to a round bottom flask containing a blue solution of complex 5 (200.0 mg, $0.22 \mathrm{mmol}, 1$ equiv.) in dichloromethane (15 $\mathrm{mL}$ ). The mixture was stirred at r.t. open to the air. After 3 days, the solvent was removed to obtain a brown residue which was dissolved in acetone to obtain a brown solution and a blue precipitate (complex 5). The solution was filtered to separate the starting material from the desired product. Then, the solvent was removed and the resulting compound was purified by trituration with diethyl ether and recrystallized from acetone to give brown crystals at room temperature. Yield: $33.0 \mathrm{mg}$ (0.05 mmol, $23 \%) .{ }^{1} \mathrm{H}$ NMR $\left(\mathrm{CD}_{2} \mathrm{Cl}_{2}, 500 \mathrm{MHz}, \mathrm{RT}\right)$ : diamagnetic spectrum, $\delta=10.34\left(\mathrm{~d},{ }^{3} J=\right.$ $\left.5.0 \mathrm{~Hz}, 1 \mathrm{H}, \mathrm{C} H_{\mathrm{pyr}}\right), 8.20\left(\mathrm{t},{ }^{3} \mathrm{~J}=6.0 \mathrm{~Hz}, 1 \mathrm{H}, \mathrm{C} H_{\mathrm{pyr}}\right), 8.07\left(\mathrm{~d},{ }^{3} \mathrm{~J}=7.0 \mathrm{~Hz}, 1 \mathrm{H}, \mathrm{C} H_{\mathrm{pyr}}\right), 7.86\left(\mathrm{t},{ }^{3} J=\right.$ $\left.6.0 \mathrm{~Hz}, 1 \mathrm{H}, \mathrm{CH}_{\mathrm{pyr}}\right), 7.82\left(\mathrm{~d},{ }^{3} J=7.0 \mathrm{~Hz}, 1 \mathrm{H}, \mathrm{C} H_{\mathrm{pyr}}\right), 7.61\left(\mathrm{t},{ }^{3} \mathrm{~J}=6.0 \mathrm{~Hz}, 1 \mathrm{H}, \mathrm{C} H_{\mathrm{pyr}}\right), 6.80(\mathrm{~s}, 1 \mathrm{H}$, $\left.\mathrm{CH}_{\mathrm{Ar}}\right), 6.76\left(\mathrm{~d},{ }^{3} J=5.0 \mathrm{~Hz}, 1 \mathrm{H}, \mathrm{CH}_{\mathrm{pyr}}\right), 6.72-6.67\left(\mathrm{~m}, 3 \mathrm{H}, 2 \mathrm{C} H_{\mathrm{Ar}}\right.$ and $\left.1 \mathrm{CH}_{\mathrm{pyr}}\right), 6.66(\mathrm{~s}, 1 \mathrm{H}$, $\left.\mathrm{CH}_{\mathrm{Ar}}\right), 6.41\left(\mathrm{~s}, 2 \mathrm{H}, \mathrm{CH}_{\mathrm{Ar}}\right), 3.82\left(\mathrm{~d},{ }^{2} J=10.0 \mathrm{~Hz}, 2 \mathrm{H}, \mathrm{ArCH}_{2} \mathrm{~N}\right), 3.49\left(\mathrm{~s} \mathrm{br}, 2 \mathrm{H}, \operatorname{ArCH}_{2} \mathrm{~N}\right), 3.24(\mathrm{~d}$, $\left.{ }^{2} J=13.0 \mathrm{~Hz}, 2 \mathrm{H}, \mathrm{ArCH}_{2} \mathrm{~N}\right), 2.44\left(\mathrm{~s}, 3 \mathrm{H}, \mathrm{ArCH}_{3}\right), 2.13\left(\mathrm{~s}, 3 \mathrm{H}, \mathrm{ArCH}_{3}\right), 2.08\left(\mathrm{~s}, 6 \mathrm{H}, \mathrm{ArCH}_{3}\right), 1.40$ (s, $\left.6 \mathrm{H}, \mathrm{ArCH}_{3}\right) ;{ }^{13} \mathrm{C}\left\{{ }^{1} \mathrm{H}\right\}$ NMR $\left(\mathrm{CD}_{2} \mathrm{Cl}_{2}, 126 \mathrm{MHz}, \mathrm{RT}\right): \delta=160.8\left(C_{\mathrm{q}}\right), 158.3\left(C_{\mathrm{q}}\right), 157.5\left(C_{\mathrm{q}}\right)$, $156.6\left(C_{\mathrm{q}}\right), 152.1\left(C \mathrm{H}_{\mathrm{pyr}}\right), 151.5\left(\mathrm{CH}_{\mathrm{pyr}}\right), 139.0\left(C \mathrm{H}_{\mathrm{pyr}}\right), 138.2\left(C \mathrm{H}_{\mathrm{pyr}}\right), 131.8\left(C_{\mathrm{q}}\right), 131.5\left(C_{\mathrm{Ar}}\right)$, $130.1\left(C_{\mathrm{q}}\right), 130.0\left(\mathrm{CH}_{\mathrm{Ar}}\right), 127.5\left(C_{\mathrm{q}}\right), 126.8\left(C \mathrm{H}_{\mathrm{Ar}}\right), 123.7\left(C_{\mathrm{q}}\right), 123.5\left(C_{\mathrm{q}}\right), 123.1\left(C \mathrm{H}_{\mathrm{pyr}}\right), 122.2$ $\left(\mathrm{CH}_{\mathrm{pyr}}\right), 120.5\left(\mathrm{CH}_{\mathrm{pyr}}\right), 120.4\left(\mathrm{CH}_{\mathrm{pyr}}\right), 64.9\left(\mathrm{ArCH}_{2} \mathrm{~N}\right), 61.8\left(\mathrm{ArCH}_{2} \mathrm{~N}\right), 20.4\left(\mathrm{ArCH}_{3}\right), 20.2$ $\left(\mathrm{ArCH}_{3}\right), 19.1\left(\mathrm{ArCH}_{3}\right), 16.2\left(\mathrm{ArCH}_{3}\right) ; \mathrm{MALDI}(+)-\mathrm{MS}$ (dctb): $\mathrm{m} / \mathrm{z}=631.4$ [M] $]^{+.}$(calcd. 631.2); 
Anal. calcd. for $\mathrm{C}_{37} \mathrm{H}_{38} \mathrm{CoN}_{3} \mathrm{O}_{3} \cdot 2 \mathrm{H}_{2} \mathrm{O}$ : C 66.56, H 6.34, N 6.29; found: $\mathrm{C} 66.04, \mathrm{H}$ 5.91, N 6.43. IR $\left(\mathrm{cm}^{-1}\right): 2973,2906,2856,1605,1470,1443,1310,1267,1157,1033,854,804,766,730,607$ 556, 500, $408(\mathrm{~m})$; UV/Vis $\left(\mathrm{CH}_{2} \mathrm{Cl}_{2}, 0.2 \mathrm{mM}, 25^{\circ} \mathrm{C}, \varepsilon=\mathrm{L} \cdot \mathrm{mol}^{-1} \cdot \mathrm{cm}^{-1}\right): 356 \mathrm{~nm}(4307), 468 \mathrm{~nm}$ (2140).

X-ray diffraction studies. The measured crystals were stable under atmospheric conditions; nevertheless they were treated under inert conditions immersed in perfluoropolyether as protecting oil for manipulation. Data Collection: measurements were made on a Bruker-Nonius diffractometer equipped with an APPEX II 4K CCD area detector, a FR591 rotating anode with MoKa radiation, Montel mirrors and a Kryoflex low temperature device $\left(\mathrm{T}=-173^{\circ} \mathrm{C}\right)$. Full-sphere data collection was used with $\omega$ and $\varphi$ scans. Programs used: Data collection Apex2 V2011.3 (Bruker-Nonius 2008), data reduction Saint+Version 7.60A (Bruker AXS 2008) and absorption correction SADABS V. 2008-1 (2008). Structure Solution: SHELXTL Version 6.10 (Sheldrick, 2000) was used. ${ }^{17}$ Structure Refinement: SHELXTL-97-UNIX VERSION.

Crystallographic data for complex 5. $\mathrm{C}_{62} \mathrm{H}_{76} \mathrm{CoN}_{2} \mathrm{O}_{7}, M_{\mathrm{r}}=1020.17$, monoclinic, $C \mathrm{c}, a=$ 14.3608(6) $\AA, b=24.8788(13) \AA, c=16.2469(7) \AA, \alpha=\gamma=90^{\circ}, \beta=90.053(2)^{\circ}, V=5804.7(5)$ $\AA^{3}, Z=4, \rho=1.167 \mathrm{mg} \cdot \mathrm{M}^{-3}, \mu=0.347 \mathrm{~mm}^{-1}, \lambda=0.71073 \AA, T=100(2) \mathrm{K}, F(000)=2180$, crystal size $=0.15 \times 0.13 \times 0.10 \mathrm{~mm}, \theta(\min )=1.637^{\circ}, \theta(\max )=27.50^{\circ}, 21502$ reflections collected, 12701 reflections unique $\left(R_{\text {int }}=0.0399\right), \mathrm{GoF}=1.027, R_{1}=0.0867$ and $w R_{2}=0.2267[\mathrm{I}>2 \sigma(\mathrm{I})]$, $R_{1}=0.1290$ and $w R_{2}=0.2629$ (all indices), Flack parameter: $\mathrm{x}=0.51(4), \min / \mathrm{max}$ residual density $=-0.369 / 1.214\left[\mathrm{e} \cdot \AA^{-3}\right]$. Completeness to $\theta\left(27.50^{\circ}\right)=99.8 \%$. The structure is disordered over two positions (70:30 occupancy ratio) and is a $\mathrm{MeOH} /$ toluene solvate.

Crystallographic data for complex 6a. $\mathrm{C}_{78} \mathrm{H}_{109} \mathrm{Co}_{2} \mathrm{~N}_{2} \mathrm{Na}_{3} \mathrm{O}_{13}, M_{\mathrm{r}}=1469.50$, monoclinic, $P \mathrm{n}$, $a=13.7435(14) \AA, b=26.138(3) \AA, c=21.020(2) \AA, \alpha=\gamma=90^{\circ}, \beta=90.337(2)^{\circ}, V=7550.9(13)$ 
$\AA^{3}, Z=2, \rho=1.293 \mathrm{mg} \cdot \mathrm{M}^{-3}, \mu=0.519 \mathrm{~mm}^{-1}, \lambda=0.71073 \AA, T=100(2) \mathrm{K}, F(000)=3128$, crystal size $=0.13 \times 0.10 \times 0.10 \mathrm{~mm}, \theta(\min )=0.779^{\circ}, \theta(\max )=35.34^{\circ}, 320726$ reflections collected, 48572 reflections unique $\left(R_{\mathrm{int}}=0.0385\right), \mathrm{GoF}=1.017, R_{1}=0.0370$ and $w R_{2}=0.0916[\mathrm{I}>2 \sigma(\mathrm{I})]$, $R_{1}=0.0460$ and $w R_{2}=0.0972$ (all indices), Flack parameter: $\mathrm{x}=0.393(6), \mathrm{min} / \mathrm{max}$ residual density $=-0.455 / 0.720\left[\mathrm{e} \cdot \AA^{-3}\right]$. Completeness to $\theta\left(35.34^{\circ}\right)=95.3 \%$. The structure is a THF solvate and it contains two distinct complexes in the unit cell.

Crystallographic data for complex 6 b. $\mathrm{C}_{73} \mathrm{H}_{79} \mathrm{CoN}_{3} \mathrm{O}_{5} \mathrm{P}_{2}, M_{\mathrm{r}}=1199.26$, monoclinic, $P 2(1), a$ $=14.1572(11) \AA, b=13.5823(12) \AA, c=17.1867(17) \AA, \alpha=\gamma=90^{\circ}, \beta=107.672(3)^{\circ}, V=$ $3148.8(5) \AA^{3}, Z=2, \rho=1.265 \mathrm{mg} \cdot \mathrm{M}^{-3}, \mu=0.377 \mathrm{~mm}^{-1}, \lambda=0.71073 \AA, T=100(2) \mathrm{K}, F(000)=$ 1270 , crystal size $=0.20 \times 0.10 \times 0.03 \mathrm{~mm}, \theta(\min )=1.51^{\circ}, \theta(\max )=30.55^{\circ}, 24268$ reflections collected, 14719 reflections unique $\left(R_{\text {int }}=0.0265\right), \mathrm{GoF}=1.026, R_{1}=0.0425$ and $w R_{2}=0.0943[\mathrm{I}$ $>2 \sigma(\mathrm{I})], R_{1}=0.0549$ and $w R_{2}=0.1005$ (all indices), Flack parameter: $\mathrm{x}=0.015(6), \mathrm{min} / \mathrm{max}$ residual density $=-0.558 / 0.529\left[\mathrm{e} \cdot \AA^{-3}\right]$. Completeness to $\theta\left(30.55^{\circ}\right)=96.7 \%$. The structure has a disorder in the coordinated THF molecule and co-crystallized $\mathrm{CH}_{3} \mathrm{CN}$, and the absolute configuration was determined.

Crystallographic data for complex 7. $\mathrm{C}_{42} \mathrm{H}_{52} \mathrm{Cl}_{2} \mathrm{CoN}_{5} \mathrm{O}_{3}, M_{\mathrm{r}}=804.71$, triclinic, $P-1, a=$ 11.4464(6) $\AA, b=12.3420(6) \AA, c=15.9066(7) \AA, \alpha=108.305(2)^{\circ}, \beta=99.116(2)^{\circ}, \gamma=$ $104.538(2)^{\circ}, V=1995.11(17) \AA^{3}, Z=2, \rho=1.340 \mathrm{mg} \cdot \mathrm{M}^{-3}, \mu=0.609 \mathrm{~mm}^{-1}, \lambda=0.71073 \AA, T=$ $100(2) \mathrm{K}, F(000)=848$, crystal size $=0.15 \times 0.08 \times 0.04 \mathrm{~mm}, \theta(\min )=1.902^{\circ}, \theta(\max )=28.30^{\circ}$, 9576 reflections collected, 9576 reflections unique, $\mathrm{GoF}=1.039, R_{1}=0.0431$ and $w R_{2}=0.0999$ $[\mathrm{I}>2 \sigma(\mathrm{I})], R_{1}=0.0586$ and $w R_{2}=0.1072$ (all indices), Flack parameter: $\mathrm{x}=0.393(6), \mathrm{min} / \mathrm{max}$ residual density $=-0.471 / 0.394\left[\mathrm{e} \cdot \AA^{-3}\right]$. Completeness to $\theta\left(28.30^{\circ}\right)=96.4 \%$. For this structure the 
program TWINABS was used ${ }^{18}$ since the two types of monocrystals had formed. The structure contains a disordered, modeled DCM molecule.

Cyclic voltammetry. Cyclic voltammetry measurements were carried out with a Princeton Applied Research PARSTAT 2273 electrochemical analyzer. A three-component system consisting of a glassy carbon working electrode, a platinum wire auxiliary electrode and $\mathrm{Ag}-\mathrm{AgCl}$ (sat. $\mathrm{NaCl}$ ) reference electrode was used. All experiments were done under argon atmosphere at r.t. and in dichlorometane solutions with $0.2 \mathrm{M}$ tetrabuthylammonium hexafluorophosphate $\left(\mathrm{NBu}_{4} \mathrm{PF}_{6}\right)$ as the supporting electrolyte.

Magnetic data. Magnetic susceptibility measurements with polycrystalline samples of complexes 4-8 were carried out in a Quantum Design MPMS-XL-7 SQUID magnetometer using a field of 1000 Oe in the 2-300 K temperature range. Pascal's constants were used to estimate the diamagnetic corrections for the compounds.

\section{ASSOCIATED CONTENT}

Supporting Information. X-ray crystallographic data in CIF format, further experimental details and spectroscopic data of key compounds. This material is free of charge via the Internet at http://pubs.acs.org.

\section{AUTHOR INFORMATION}

\section{Corresponding Author}

*E-mail: akleij@iciq.es. Phone: +34 -977920247. Fax: +34 - 977920823.

\section{Notes}


The authors declare no competing financial interest.

\section{ACKNOWLEDGMENT}

We thank ICIQ, ICREA, the Spanish Ministerio de Economía y Competitividad (MINECO) through project CTQ-2011-27385 and support through Severo Ochoa Excellence Accreditation 2014-2018 (SEV-2013-0319), and the European Union through project ERC Stg grant CHEMCOMP for support. CM gratefully thanks the Marie Curie COFUND Action from the European Commission for co-financing a postdoctoral fellowship. Dr. Noemí Cabello, Sofía Arnal and Vanessa Martínez are thanked for the MS analyses.

\section{REFERENCES}

(1) Licini, G.; Mba, M.; Zonta, C. Dalton Trans. 2009, 5265-5277.

(2) (a) Kim, Y.; Jnaneshwara, G. K.; Verkade, J. G. Inorg. Chem. 2003, 42, 1437-1447. (b) Mba, M.; Prins, L. J.; Licini, G. Org. Lett. 2007, 9, 21-24. (c) Mba, M.; Pontini, M.; Lovat, S.; Zonta, C.; Bernardelli, G.; Kundig, P. E.; Licini, G. Inorg. Chem. 2008, 47, 8616-8618. (d) Romano, F.; Linden, A.; Mba, M.; Zonta, C.; Licini, G. Adv. Synth. Catal. 2010, 352, 2937-2942. (e) Chmura, A. J.; Davidson, M. G.; Frankis, C. J.; Jones, M. D.; Lunn, M. D. Chem. Commun. 2008, 12931295. (f) Lam, O. P.; Anthon, C.; Meyer, K. Dalton Trans. 2009, 9677-9691. (g) Whiteoak, C. J.; Gjoka, B.; Martin, E.; Martínez Belmonte, M.; Zonta, C.; Licini, G.; Kleij, A. W. Inorg. Chem. 2012, 51, 10639-10649; (h) Whiteoak, C. J.; Martin, E.; Martínez Belmonte, M.; Benet-Buchholz, J.; Kleij, A. W. Adv. Synth. Catal. 2012, 354, 469-476; (i) Whiteoak, C. J.; Martin, E.; Escudero- 
Adán, E. C.; Kleij, A. W. Adv. Synth. Catal. 2013, 355, 2233-2239; (j) Whiteoak, C. J.; Kielland, N.; Laserna, V.; Escudero-Adán, E. C.; Martin, E.; Kleij, A. W. J. Am. Chem. Soc. 2013, 135, 1228-1231; (k) Whiteoak, C. J.; Kielland, N.; Laserna,V.; Castro-Gómez, F.; Martin, E.; EscuderoAdán, E. C.; Bo, C.; Kleij, A. W. Chem. Eur. J. 2014, 20, 2264-2275. (1) Su, W.; Kim, Y.; Ellern, A.; Guzei, I. A.; Verkade, J. G. J. Am. Chem. Soc. 2006, 128, 13727-13735.

(3) Käß, M.; Hohenberger, J.; Adelhardt, M.; Zolnhofer, E. M.; Mossin, S.; Heinemann, F. W.; Sutter, J.; Meyer, K. Inorg. Chem. 2014, 53, 2460-2470.

(4) (a) Ray, M.; Hammes, B. S.; Yap, G. P. A.; Rheingold, A. L.; Borovik, A. S. Inorg. Chem. 1998, 37, 1527-1532. (b) Stähler, R.; Bensch, W. Eur. J. Inorg. Chem. 2001, 3073-3078. (c) Searls, C. E.; Kleespies, S. T.; Eppright, M. L.; Schwartz, S. C.; Yap, G. P. A.; Scarrow, R. C. Inorg. Chem. 2010, 49, 11261-11263. (d) Suh, M. P; Lee, J.; Han, M. Y.; Yoon, T. S. Inorg. Chem. 1997, 36, 5651-5654. (e) El-Shafai, N. M.; Ibrahim, M. M.; Kamel, G. E.; El-Baradie, H. Y. J. Mater. Environ. Sci. 2012, 3, 1101-1108. (f) Lucas, R. L.; Zart, M. K.; Murkerjee, J.; Sorrell, T. N.; Powell, D. R.; Borovik, A. S. J. Am. Chem. Soc. 2006, 128, 15476-15489. (g) Jones, M. B.; MacBeth, C. E. Inorg. Chem. 2007, 46, 8117-8119. (h) Hu, X.; Castro-Rodriguez, I.; Meyer, K. J. Am. Chem. Soc. 2004, 126, 13464-13475. (i) Hu, X.; Meyer, K. J. Am. Chem. Soc. 2004, 126, $16322-16323$.

(5) (a) Tokunaga, M.; Larrow, J. F.; Kakiuchi, F.; Jacobsen, E. N. Science, 1997, 277, 936-938. (b) Jacobsen, E. N. Acc. Chem. Res. 2000, 33, 421-431. (c) Zheng, X.; Jones, C. W.; Weck, M. J. Am. Chem. Soc. 2007, 129, 1105-1112. (d) Wezenberg, S. J.; Kleij, A. W. Adv. Synth. Catal. 2010, 352, 85-91. (e) Holbach, M.; Weck, M. J. Org. Chem. 2006, 71, 1825-1836. 
(6) (a) Nakano, K.; Hashimoto, S.; Nakamura, M.; Kamada, T.; Nozaki, K. Angew. Chem. Int. Ed. 2011, 50, 4868-4871. (b) Lu, X.-B.; Shi, L.; Wang, Y.-M.; Zhang, R.; Zhang, Y.-J.; Peng, X.J.; Zhang, Z.-C.; Li, B. J. Am. Chem. Soc. 2006, 128, 1664-1674. (c) Wu, G.-P.; Wei, S.-H.; Ren, W.-M.; Lu, X.-B.; Xu, T.-Q.; Darensbourg, D. J. J. Am. Chem. Soc. 2011, 133, 15191-15199. (d) Cohen, C. T.; Chu, T.; Coates, G. W. J. Am. Chem. Soc. 2005, 127, 10869-10878.

(7) (a) Hirahata, W.; Thomas, R. M.; Lobkovsky E. B.; Coates, G. W. J. Am. Chem. Soc. 2008, 130, 17658-17659. (b) Park, J.; Lang, K.; Abboud, K. A.; Hong, S. J. Am. Chem. Soc. 2008, 130, 16484-16485.

(8) Nielsen, L. P. C.; Stevenson, C. P.; Blackmond, D. G.; Jacobsen, E. N. J. Am. Chem. Soc. 2004, 126, 1360-1362.

(9) (a) Fortner, K. C.; Bigi, J. P.; Brown, S. N. Inorg. Chem. 2005, 44, 2803-2814. (b) Zonta, C.; Licini, G. Chem. Eur. J. 2013, 19, 9438-9441.

(10) Taherimehr, M.; Al-Amsyar, S. M.; Whiteoak, C. J.; Kleij, A. W.; Pescarmona, P. P. Green Chem. 2013, 15, 3082-3090.

(11) Lehtonen, A.; Kessler, V. G Inorg. Chem. Commun. 2004, 7, 691-693.

(12) (a) Prins, L. J.; Blázquez, M. M.; Kolarović, A.; Licini, G. Tetrahedron Lett. 2006, 47, 2735-2738. (b) Chandrasekaran, A.; Day, R. O.; Holmes, R. R. J. Am. Chem. Soc. 2000, 122, 10661072.

(13) The corresponding Co(II) complex from ligand 3 could not be isolated probably due to steric restrictions; upon isolation only the starting materials were recovered. 
(14) Note that the synthesis, using the same time frame, under nitrogen or argon afforded in both cases a $17 \%$ of 7 , whereas its synthesis in a glove box gave only $8 \%$ isolated yield. This indicates that oxygen may be actively involved promoting the formation of complex 7 being one of the oxidizing sources.

(15) Jaynes, B. S.; Ren, T.; Liu, S.; Lippard, S. J. J. Am. Chem. Soc. 1992, 114, 9670-9671.

(16) Kol, M.; Shamis, M.; Goldberg, I.; Goldschmidt, Z.; Alfi, S., Hayut-Salant, E. Inorg. Chem. Comm. 2001, 4, 177-179.

(17) Sheldrick, G. M. SHELXTL Crystallographic System, version 6.10, Bruker AXS, Inc., Madison, Wisconsin, 2000.

(18) TWINABS Version 2008/4 Bruker AXS, see: Blessing, H. Acta Cryst. 1995, A51, 33-38. 
$\underline{\text { For Table of Contents only: }}$

$\mathrm{Co}(\mathrm{II})$ and $\mathrm{Co}(\mathrm{III})$ complexes comprising amino-trisphenolate ligands have been prepared and fully characterized. X-ray analyses, variable temperature NMR measurements and SQUID magnetization studies were conducted to support the oxidation states of the obtained complexes. One of the isolated Co(III) derivatives shows fluxional ligand coordination behavior in solution allowing for penta- and hexa-coordinated species to be identified in the high and low-temperature regimes, respectively.

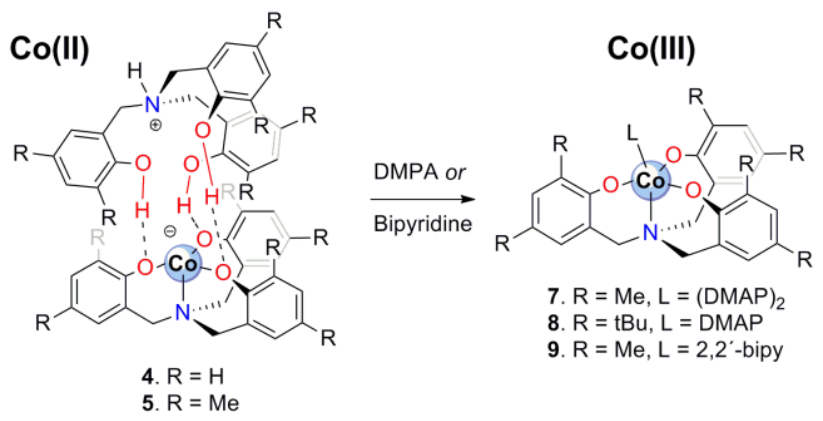

